\title{
PHYTOREMEDIATION OF POLLUTED SOIL AT TWO SITES IN THE DISTRICT OF KLAIPEDA (LITHUANIA)
}

\author{
Rapolas Liužinas ${ }^{1}$ \\ Karolis Jankevičius ${ }^{I}$ \\ Mudis Šalkauskas', \\ Valerijus Rašomavičius ${ }^{2}$ \\ Zigmantas Gudžinskas ${ }^{2}$ \\ Zofija Sinkevičiené⿱ $\dot{e}^{2}$ \\ ${ }^{1}$ Public Establishment 'Soil Remediation Technologies, 'Lithuania \\ ${ }^{2}$ Institute of Botany, Lithuania \\ Corresponding author: Rapolas Liužinas
}

\begin{abstract}
The vegetation cover of two sites contaminated with heavy fractions oil products: Klaipeda State Oil Terminal (KSOT) of 130,000 sq. m area, and Pauosčio Railway Station (PRS) of 60,000 sq. $\mathrm{m}$ area - has been investigated.

It has been established, that phytotoxical effect begins with heavy oil concentrations reaching $1000 \mathrm{~g} / \mathrm{m}^{2}$ or $5000 \mathrm{mg}$ per $1 \mathrm{~kg}$ of dry soil. Such heavy oil contains predominantly tar (by 55 percent) and light hydrocarbons (below $\mathrm{C}_{28}$ ) composed of the following factions (in percentage): paraffin-naphtene hydrocarbons -15 , olefins and cyclodiolefines -5 , alkilaromatic -1 , alkidiaromatic -4 , polyaromatic -20 .

Also, plant species and communities have been identified. The KSOT site has been found to nurture 271 species of vascular plants. The most part of this flora consists of referral plants and those specific for littoral sands. The most polluted area has been found to nurture 38 plant species.

The most resistant to the fuel oil pollution are plants having long rootstocks and long taproots: Calamagrostis epigejos, Carex hirta, Elytrigia repens, Leymus arenarius, Poa compressa, Artemisia campestris, Cirsium arvense, Convolvulus arvensis, Tanacetum valgare, Tussilago farfara. Some of them can be used in ex-situ remediation of the oilpolluted soil at biodegradation ranges. They can also be used as model plants in experimental selection of cultivated plants for bioremediation purposes.
\end{abstract}




\section{INTRODUCTION}

Recent times have witnessed increasing interest in application of higher plants and their root systems to the remediation of soil contaminated with heavy metals, pesticides, oil and its products.

Plant roots are renown for their well-developed extracellular proteolitic activity. Owing to it, some organic nitrogen compounds, otherwise hardly accessible for soil microorganisms, become easily assimilated. Also, the phosphorization activity of plant roots activates transformation of the soil organophosphates and other phosphorous compounds. Thus, phosphorus is more easily assimilated by both heterotrophic and (in case of oil pollution) oil-oxidizing microorganisms.

In 1994, general reconstruction of both KSOT and PRS has given us unique opportunity to investigate the vegetation cover of these sites. It also has provided for remediation of the soil contaminated with oil products (fuel oil) under the assumption that specifically resistant higher plants can be used for biodestruction of the fuel oil in the soil contaminated to a certain level of concentration of this pollutant.

\section{OBJECTIVES}

To investigate composition of plant species and communities at KSOT and PRS sites.

To establish plant rhizosphere properties with respect to different pollution conditions.

To find out and assess species the most resistant to oil pollution being potentially applicable to phytoremediation of the soil contaminated with fuel oil.

\section{MEANS AND METHODS}

Designing the reconstruction of KSOT (130,000 sq. m) and PRS (60,000 sq. m) sites (see Fig. 1), it has been decided to investigate their soil and groundwater contamination with oil products in order to provide for subsequent remediation.

Following this decision, an integrated hydrogeological, ecogeological and geobotanical assessment of both KSOT and PRS sites has been carried out followed by preparation of soil remediation technologies and construction of a special soil remediation plant outside Klaipeda (in vicinity of Kiškènai village) using soil-washing and seeding with oiloxidizing microorganisms (i.e. bioremediation) techniques.

To date, both soil remediation and reconstruction of KSOT and PRS have been completed.

This publication presents some fragments of geobotanical investigations that have been carried out at KSOT and PRS sites. They are attributable to the domain of phytoremediation. 
KALMAR ECO-TECH'03

Bioremediation and Leachate Treatment

KALMAR, SWEDEN, November 25-27, 2003

Vegetation cover investigations (specific and communal) have been carried out using botanical field investigation methodology.

Floral investigation method. All identified species have been recorded assessing their proliferation, habitats and individual abundance in each of them. To identify species, some works of SNARSKIS $(1954,1958)$, ROTHMALER (1986), NATKEVIČAITĖIVANAUSKIENE (1963), JANKEVIČIENE (1998), FLORA EUROPAEA (1964-1980), etc. have been used.

Vegetation community investigation method. Vegetation communal diversification investigation has been carried out using geobotanical descriptions. In defining communities, the following criteria have been applied:

a) Magnitude of representation of each species population in a community, in points by BRAUN-BLANQUET (1964) scale:

+ few individuals covering very little area,

1 - a number of individuals with little coverage, or a less number with wider coverage, however, not reaching $1 / 20$ of the area,

2 - quite a lot of individuals, or they cover at least $1 / 20$ of the area,

3 - a variety of individuals covering $1 / 4-1 / 2$ of the plot,

$4-$ a variety of individuals covering $1 / 2-3 / 4$ of the plot,

5 - a variety of individuals covering over $3 / 4$ of the plot.

b) Species fertility, in points by the following scale:

0 - No fertile individuals,

1 - Fertile individuals amount to less than 10 percent of population,

2 - Fertile individuals amount to 10 and more percent.

c) Vertical structure of communities. In herbal communities (almost entirely predominant on the investigated area), their vertical distribution differences have been perceived as a vertical continuum of communities, therefore, separate description, assessment and analysis have been given for the totality of herbal tier and for the surface moss-lichen tier only.

d) Community horizontal mosaic. Horizontal distribution of individuals within populations has been identified including the nature of their concentration, i.e. whether they grow singly, in small groups or sporadic families, in spots, colonies, or thickets; as well as population distribution within communities: random; even; in various combinations.

e) Community general projection coverage, in percentage. 


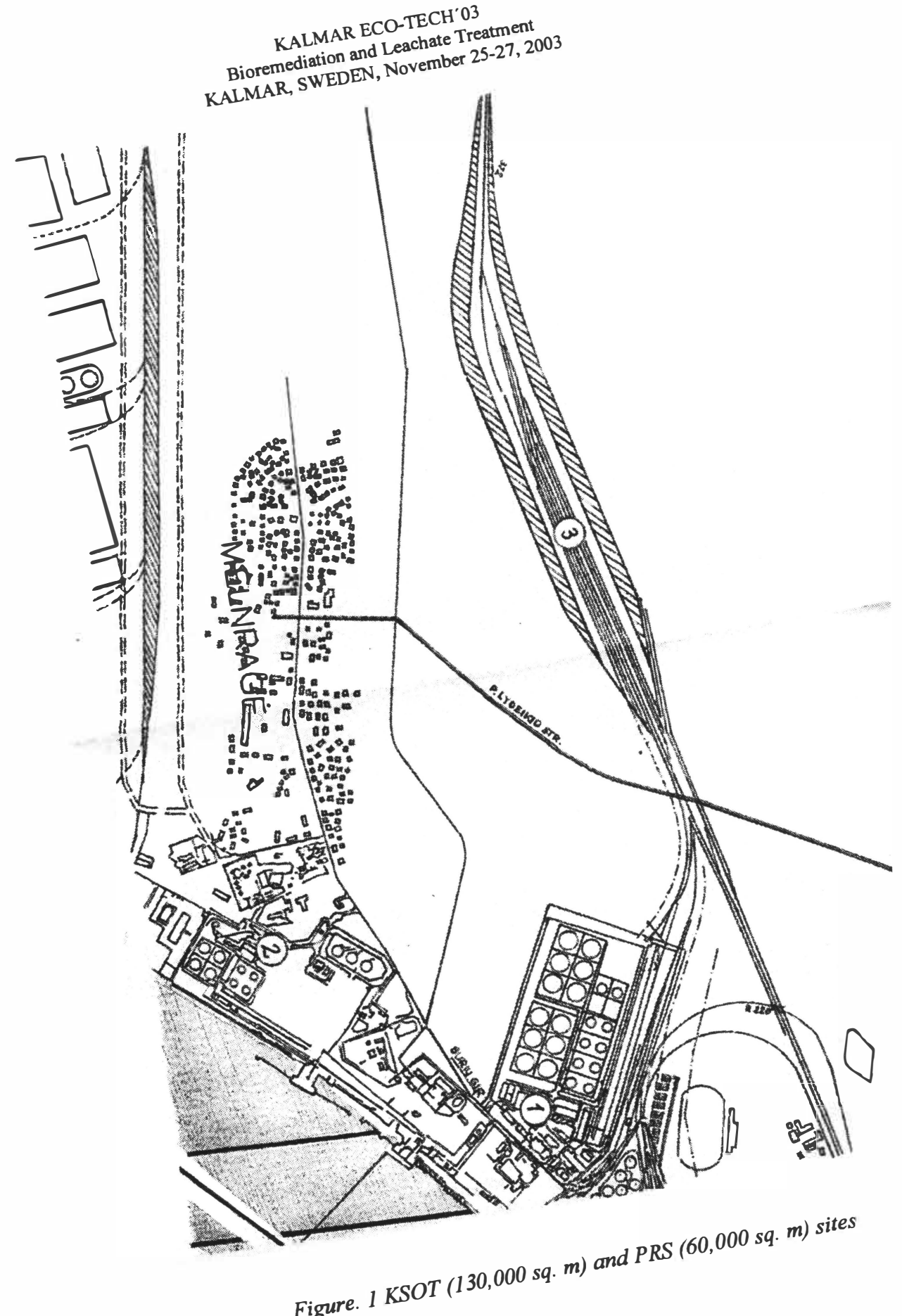


Syntaxonomical relationship of the described communities has been identified basing on the authors' experience and publications (OBERDORFER, 1978, 1983; MATUSZKIEWICZ, 1984; BALEVIČIENĖ, 1991).

Rhizological investigations. Species and community investigations by subterranean parts have been carried out following the approbated method (LAPINSKIENE, 1986), by excavation of cross-sections and monoliths, separation of subterranean parts, and assessment of both nature and depth of root and rootstock arrangement as well as the density of both uncontaminated and oil-polluted soil in the cross-sections.

To assess the impact on vegetation of both subterraneous and anthropogenic factors, a transsection method has been used. Transsections have been drawn in areas of geological well-borings. All contours included in transsections have been described and, basing upon departures of their parameters from the reference ones, the nature of contamination deducted.

Both KSOT and PRS site soils belong to sandy or gravelly-sandy soil type.

The sites have been contaminated with the fuel oil. Its toxic effect on vegetation depends not only on the degree of biodegradation of this pollutant (its hydrocarbons below $\mathrm{C}_{28}$ are more easily destructible while those above $\mathrm{C}_{28}$ - resins - are hardly destructible), but also on proportions of pollutants with different nature, their interaction, and on particular ecological conditions.

The KSOT site has been contaminated by the fuel oil altered by long-lasting biodegradation. The PRS site has often been contaminated with the fuel oil containing almost 45 percent of light hydrocarbon (below $\mathrm{C}_{28}$ ) factions.

Experience has shown that suppression of development of the vegetation cover (phytotoxical effect) begins with the fuel oil concentration exceeding 5,000 mg per $1 \mathrm{~kg}$ of dry soil, or $1,000 \mathrm{~g} / \mathrm{m}^{2}$. Such fuel oil has the following composition (in percentage): paraffin-naphtene hydrocarbons -15 , olephines and cyclodiolephines -5 , alkylaromatic hydrocarbons -1 , alkydiaromatic hydrocarbons -4 , polyaromatic hydrocarbons -20 , benzene resins -30 , alcohol-benzene resins -20 . Light hydrocarbon (below $\mathrm{C}_{28}$ ) analysis has been carried out with Dani 86.10 chromatographer using both headspace $\left(C_{6}-C_{10}\right)$ and direct injection $\left(\mathrm{C}_{10}-\mathrm{C}_{28}\right)$ methods and FID detector.

Background concentration of natural hydrocarbons in the soils of KSOT and PRS has been found to exceed $20 \mathrm{mg} / \mathrm{kg}$ of dry soil (PUSTELNIKOVAS, 1994).

\section{FLORAL CHARACTERISTICS OF KSOT SITE}

Totally 271 higher plant species belonging to 48 families have been recorded at the KSOT site. Its floral composition is characteristic for technogenic biotops. Most species belong to Asteraceae (38 species), Poaceae (37 species), Brassicaceae (22 species), Fabaceae (19 species), Caryophyllaceae (16 species) and Rosaceae (13 species) families. 
Abundance of Brassicaceae and Caryophyllareae family species is typical for all technogenic biotops existing in various climatic and geographic zones (CHARCHOTA, 1989; PASYNKOVA, 1989; TERECHOVA, 1989; CHYŽNIAK, DACUN, 1989).

\section{PLANT COMMUNITIES AT KSOT SITE}

Plant groupings overspreading the KSOT site can be classified by their degree of athropogenization into the following groups:

1. Relatively natural communities or their fragments. They are either remnants of potential vegetation, or natural anthrop tolerant plant communities. This group is represented by:

a) Corynephorion union psammophite (sand plants) communities. They cover limited areas, however, their communities are quite diversified by both species saturation and their degree of concentration. They can be found in initial phase of introduction to sandy soil with prevailing annual plants; more recent patches are richer with Corynephorus canescens, Festuca ovina, Festuca sabulosa humps, finally forming relatively thick sandsoil grassland with prevailing Carex arenaria;

b) Fragments of communities appropriate to littoral sand dunes, of Ammophiletea class. Its most common representatives at the site are thickets of Leymus arenarius;

c) Molinio-Arrhenatheretea class communities characteristic for mezophylic meadows. His class is represented by Calt hion grouping's communities with either prevailing Juncus effusus, Glyceria fluitans, Holcus lanatus vegetating on small plots with excess watering, or a small fragment of Agrostietalia series communities preferring salty and moist soil. It is noteworthy that in these communities, alongside with characteristic syntaxonic species (Agrostis stolonifera, Trifolium fragiferum, etc.), there also grows Glaux maritima - a species listed in the Red Data Book of Lithuania; other communities belonging to the same series are found on quite large plots of pressurized waterproof soil of rather heavy mechanical composition. There also prevails the leaning Agrostis stolonifera, quite widespread are Polygonum aviculare, Carex hirta, Trifolium repens, Polygonum amphibium.

2. Naturalized vegetation. Communities attributable to this group have been forming on transformed soils (levelled grounds, fillings, escarps) following their seeding with grass blends (e. g. Festuca rubra, Lolium perenne, Dactylis glomerata, Medicago falcata) and subsequent cross-seeding by plants either already existing in the soil or from randomly peregrinating diasporas (Carex arenaria, Medicago lupulina, Calamagrostis epigejos, Artemisia campestris etc.). Synsystematic situation of these communities have not been defined. 
3. Anthropogenic vegetation. Attributable to the investigated territory, the plants of anthropogenic origin (narrowly speaking) are considered to be mostly groupings of annual plants primarily growing on the removed soils. If their habitats are not persistently harmed in the mechanical sense, their terophyte communities are replaced by perennial vegetation composed of accidentally introduced diasporas depending on ecological conditions of their habitats. The following terophyte communities have been decrypted:

a) Communities with prevailing Anisantha tectorum and Corispermum leptopterum. They are characteristic for the initial stages of introduction into sand soils;

b) Terophyte communities belonging to Sisymbrion union. They grow on freshly-removed soils having better nutrition and irrigation conditions. The most abundant species are: Chenopodium album, Chenopodium glaucum, Tripleurospermum inodorum, Sisymbrium officinale;

c) Polygonion avicularis union communities growing on heavily trampled and otherwise pressurized soil on roadsides, waysides, and by the buildings. These communities are predominantly represented by Polygonum aviculare, sometimes Poa annua and Chamomilla suaveolens;

d) Biennial and perennial thermophillic communities of Dauco - Melilotion union. They are characteristic for later stages of the formation of free habitats. Their communities are predominantly represented by Melilotus alba, Echium vulgare, Artemisia campestris.

4. Cultivated vegetation. They are human - made and sustained plant groupings (landscape gardens, seeded lawn grass).

\section{FLORAL CHARACTERISTIC OF PRS SITE}

Heavy and persistent contamination with fuel oil makes vegetation conditions at the PRS site extraordinarily unfavourable. Upon investigation of the railway station's site (its area delimited by rail lines with interlines), totally 38 species of higher plants have been registered (see Table 1).

Table 1. List of plant species inhabiting PRS site area contaminated with oil products

\begin{tabular}{|l|l|}
\hline Species & Common name (JANKEVIČIENĖ, 1998) \\
\hline Achillea millefolium $\boldsymbol{L}$. & $\begin{array}{l}\text { Common yarrow, milfoil, bloodwort, soldiers } \\
\text { woundwort, sanquinary }\end{array}$ \\
\hline Agrostis tenuis $\boldsymbol{L}$. & Common bent-grass, fine bent-gras, colonial bent \\
\hline
\end{tabular}


KALMAR ECO-TECH'03

Bioremediation and Leachate Treatment

KALMAR, SWEDEN, November 25-27, 2003

\begin{tabular}{|c|c|}
\hline Anisantha sterilis (L.) Nevski & Barren brome \\
\hline Anisantha tectorum (L.) Nevski & $\begin{array}{l}\text { Junegrass, drooping brome, roof brome-grass, } \\
\text { military grass }\end{array}$ \\
\hline Artemisia campestris $L$. & Field sagebrush, sagewort worm wood \\
\hline Artemisia vulgaris $L$. & Mugwort worm wood, felon herb \\
\hline Betula pendula Roth & Common birch, silver birch \\
\hline Conyza canadensis (L.) Crong & $\begin{array}{l}\text { Horseweed, colt's tail, butterweed, prideweed, } \\
\text { Canadian fleabane }\end{array}$ \\
\hline Calamagrostis epigeios (L.) Roth & Bushgrass, feathertop-grass \\
\hline Carex arenaria $L$. & $\begin{array}{l}\text { Sand-sedge, common sand sedge, creeping sedge, } \\
\text { netrein }\end{array}$ \\
\hline Carex hirta $L$. & Hairy sedge, hammer sedge \\
\hline Carex leporina $L$. & Hare's-foot sedge \\
\hline Centaurea rhenana Boreau & Spotted knapweed, Rhine knapweed \\
\hline $\begin{array}{l}\text { Chamanerion angustifolium }(L .) \\
\text { Scop }\end{array}$ & $\begin{array}{l}\text { Great willow-herb, French willow, common low } \\
\text { oleander }\end{array}$ \\
\hline Cichorium intybus $L$. & Common chicory, blue sailors, wild succory \\
\hline Cirsium arvense (L.) Scop & Creeping thistle, Canada thistle \\
\hline Convolvulus arvensis $L$. & $\begin{array}{l}\text { Lesser bindweed, field bindweed, cornbind, } \\
\text { devil's guts }\end{array}$ \\
\hline Daucus carota $L$. & Wild carrot \\
\hline Elytrigia repens (L.) Nevski & $\begin{array}{l}\text { Quack-grass, common couch, scutch, twich } \\
\text { couch-grass }\end{array}$ \\
\hline Equisetum arvense $L$. & Field hosetail, common horsetail \\
\hline Hippophae rhamnoides $L$. & Common seabuck thorn \\
\hline Hypericum perforatum $L$. & $\begin{array}{l}\text { Common Saint-Johnswort, goat-weed, klamath- } \\
\text { weed }\end{array}$ \\
\hline Lactuca serriola $L$. & Prickly lettuce \\
\hline Leontodon autumnalis $L$. & Autumnal hawkbit, fall dandelion \\
\hline Leymus arenarius (L.) Hochst & Sealyme-grass \\
\hline
\end{tabular}


KALMAR ECO-TECH'03

Bioremediation and Leachate Treatment

KALMAR, SWEDEN, November 25-27, 2003

\begin{tabular}{|l|l|}
\hline Oenothera rubricaulis Klebhan & Red-stalked evening primrose \\
\hline Pastinaca sativa L. & $\begin{array}{l}\text { Common parsnip, wild parsnip, madnep, queen } \\
\text { weed }\end{array}$ \\
\hline Plantago major L. & Great plantain, greater broad-leaved plantain \\
\hline Poa annua L. & Suffolk-grass, annual meadow-grass, speargrass \\
\hline Poa compressa $L$. & $\begin{array}{l}\text { Flattened meadow-grass, Canada bluegrass, } \\
\text { English bluegrass, wire-grass }\end{array}$ \\
\hline Polygonum aviculare L. & Common Knotweed, doorweed \\
\hline Puccinellia distans (Jacg.) Parl & Reflexed saltmarshgrass, wide-spread sweetgrass \\
\hline Rumex acetosella L. & Sheep sorrel, red sorrel \\
\hline Senecio viscosus $L$. & Stinking groundsel, sticky groundsel \\
\hline Tanacetum vulgare L. & Common tansy, bitterbuttons, parsley fern \\
\hline Taraxacum officinale Wigg & Common dandelion, milk-gowan, wild endive \\
\hline Trifolium repens $L$. & $\begin{array}{l}\text { White clover, Dutch clover, shamrock, honey } \\
\text { clover }\end{array}$ \\
\hline Tussilago farfara $L$. & $\begin{array}{l}\text { Common coltsfoot, British tobacco, butterbur, } \\
\text { horsehoof }\end{array}$ \\
\hline
\end{tabular}

The heavily polluted area is inhabited mostly by members of Asteraceae family represented by 13 species, however, their abundance is rather poor. The second abundant is Poaceae family, represented by 9 species. Namely these species amount to the main part of both individuals and their biomass at this site. Cyperaceae family is represented by 3 species with 2 of them (Carex arenaria and Carex hirta) being relatively abundant.

Poaceae family plants (Calamagrostis epigejos, Poa compressa, Elytrigia repens, Leymus arenaria) are more pollution-resistant and can survive under stressful conditions.

Areas heavily polluted with fuel oil have been habitats to mosses Bryum argenteum, Funaria hygrometrica, Ceratodon purpurea, also Poa annua and Conyra canadensis. These moss species together with Conyra canadensis are considered (FRANK, KLOTZ, 1990) to be extraordinarily resistant to contamination and are attributable to the group of toxicophylliae.

\section{PLANT COMMUNITIES AT PRS SITE}

Heavily contaminated area has been usually inhabited by single plants. Small groupings of them have been formed by Calamagrostis epigejos, Carex hirta, more rarely - by Carex arenaria. The contaminated area consists of plots with various pollution levels. 
KALMAR ECO-TECH'03

Bioremediation and Leachate Treatment

KALMAR, SWEDEN, November 25-27, 2003

Plant species numbers, their composition and herbal coverage depend on the concrete level of contamination (see Tables 2 and 3).

Table 2. Specific composition of communities with Carex hirta under various contamination conditions* at PRS site in soil: 1 -sand with pieces of solidified fuel oil 2 - trampled sand periodically polluted with heavy oil 3 - gravel with oil products; 4 gravel with solidified fuel oil; 5 -soil rich in liquid oil products; 6 -semi-liquid fuel oil (on the embankment slope).

\begin{tabular}{|c|c|c|c|c|c|c|}
\hline \multirow[t]{2}{*}{ Description No } & \multicolumn{6}{|c|}{ Soil } \\
\hline & 1 & 2 & 3 & 4 & 5 & 6 \\
\hline $\begin{array}{l}\text { Herbal coverage in } \\
\text { percentage }\end{array}$ & 80 & 70 & 60 & 70 & 40 & 10 \\
\hline $\begin{array}{l}\text { Sa Moss coverage in } \\
\text { percentage }\end{array}$ & 60 & 10 & $\mathbf{0}$ & 10 & $\mathbf{0}$ & $\mathbf{0}$ \\
\hline Contamination degree & 1 & 2 & 3 & 3 & 3 & 4 \\
\hline Number of species decrypted & 15 & 16 & 11 & 8 & 9 & 4 \\
\hline Carex hirta & 2 & 3 & 3 & 3 & 3 & 1 \\
\hline Calamagrostis epigejos & 2 & + & . & . & + & + \\
\hline Daucus carota & + & + & + & . & . & + \\
\hline Elytrigia repens & + & . & + & 1 & . & . \\
\hline Artemisia campestris & 1 & 1 & . & . & + & . \\
\hline Poa compressa & + & 2 & . & + & . & . \\
\hline Poa angustifolia & 1 & + & + & . & . & . \\
\hline Artemisia vulgaris & . & . & 1 & 1 & + & . \\
\hline Centaurea rhenana & . & + & + & . & . & . \\
\hline Fesruca rubra & 1 & . &. & . & + & . \\
\hline Festuca arenaria & + & + & . & . & . & . \\
\hline Vicia cracca & + & + & . & . & . & . \\
\hline Achillea millefolium & . & + & . & + & . & . \\
\hline Equisetum arvense & . & + & . & + & . & . \\
\hline Festuca pratensis & . & + & + & . & . & . \\
\hline Dactylis glomerata & + & . & . & . & . & . \\
\hline Trifolium arvense & + & . & . & . & . & . \\
\hline Centaurea jacea & . & . & + & . & . & . \\
\hline Lotus corniculatus & . & . & + & . & . & . \\
\hline Plantago major & . & . & + & . & . & . \\
\hline Juncus conglomerates & . & . & + & . & . & . \\
\hline Hypericum perforatum & . & + & . & . & . & . \\
\hline Artemisia absinthium & . & . & . & . & + & . \\
\hline Conyza Canadensis & . & . & . & . & + & . \\
\hline Melilotus albus & . & . & . &. & . & + \\
\hline Oenothera rubricaulis & . & . & . & . & + &. \\
\hline Taraxacum officinale & . & . & . & . & + & . \\
\hline
\end{tabular}


KALMAR ECO-TECH'03

Bioremediation and Leachate Treatment

KALMAR, SWEDEN, November 25-27, 2003

\begin{tabular}{|l|l|l|l|l|l|l|}
\hline Brachythecium albicans & 2 & + &. &. &. &. \\
\hline Ceratodon purpureus & + & 1 &. & 1 &. &. \\
\hline Brachythecium rutabulum & 2 &. &. &. &. &. \\
\hline
\end{tabular}

*Contamination degree (indicating both qualitative and quantitative degradation of vegetation comparing to reference values, in percentage): 1 - light contamination (6 $10) ; 2$ - moderate contamination $(11-25) ; 3$ - intense contamination $(26-50) ; 4$ heavy contamination $(51-75)$

Table 3. Composition of Sagino-Bryetum communities on ground of 3 th -4 th pollution degrees* in Pauoste railway station yard in soil: 1 - sand with heavy oil; 2 - crust of solidified fuel oil; 3 - sand with breakstone.

\begin{tabular}{|c|c|c|c|}
\hline \multirow[t]{2}{*}{ Description No. } & \multicolumn{3}{|l|}{ Soil } \\
\hline & 1 & 2 & 3 \\
\hline Herbal cover & $\mathbf{0}$ & 20 & 20 \\
\hline Moss cover & 90 & 80 & 60 \\
\hline Brachythecium albicans & 3 & . & . \\
\hline Bryum argenteum & . & 4 & 2 \\
\hline Bryum caespiticeum & 1 & + & 1 \\
\hline Ceratodon purpureum & 3 & + & 3 \\
\hline Funaria hygrometrica & 1 & 1 & + \\
\hline Artemisia vulgaris & . & . & + \\
\hline Carex arenaria & - & . & + \\
\hline Conyza Canadensis & . & + & + \\
\hline Centaurea rhenana & - & . & + \\
\hline Leymus arenarius & - & - & 1 \\
\hline Equisetum arvense & - & . & 1 \\
\hline Oenothera rubricaulis & . & - & + \\
\hline Poatannua & . & 1 & . \\
\hline
\end{tabular}




\begin{tabular}{|l|l|l|l|}
\hline Poa compressa &. & + & 1 \\
\hline Polygonum aviculare & $\cdot$ & + & $\cdot$ \\
\hline Tripleurospermum inodorum & $\cdot$ & + & + \\
\hline
\end{tabular}

*Contamination degree (in percentage of vegetation decrease): 3 - above moderate level $(26-50) ; 4$ - heavily contaminated $(51-75)$.

Moderately and heavily contaminated sites have been found to inhabit plant communities of two types. On rather heavily contaminated area (see table 3 ), the communities are formed exclusively by moss: Brachytecium albicans, Bryum argenteum, Bryum caespitosum, Ceratodon purpureus, Funaria hygrometrica.

On the moderately contaminated area (see Table 2), vegetation cover has been formed by plants renown for their strong rootstocks and roots. Those include Carex hirta, Calamagrostis epigejos, Elytrigia repens, Artemisia campestris, etc.. Some of these plants can be used for the phytoremediation of contaminated soil.

\section{SINGULARITIES OF THE DEVELOPMENT OF PLANT ROOT SYSTEM}

Plant reaction to the contamination with oil and its products is quite uneven. Plants are very sensitive to the contamination of soil with light - or volatile - oil products (petrol, kerosene, motor oil, etc.) with relatively little doses of them being lethal for plants and their roots (MINIBAJEV et al., 1986). Contamination with heavy oil products (fuel oil), depending on its composition, is of noticeably different nature with unlike effect on plants. On the contaminated areas, some plant species extinct while other survive. Their destiny depends on biogenic properties and type of root system as well as on the concentration of light hydrocarbons (below $\mathrm{C}_{28}$ ) in the polluting fuel oil.

Calamagrotis epigejos rootstocks and roots penetrate the soil down to $10 \mathrm{~cm}$ depth, while the soil-contaminating fuel oil has already been solidified and its plant-intoxicating light factions almost entirely evaporated (see Figure 2). These plant roots cannot penetrate deeper soil layer containing less degraded fuel oil admixture.

When a soil layer heavily contaminated with oil products (fuel oil) is deeper, Calamagrostis epigejos roots penetrate down to $45 \mathrm{~cm}$ depth. Rhizosphere development of other plants under analogical soil contamination conditions is quite similar. Generally speaking, the roots of plants tolerable to the fuel oil pollution penetrate the soil to their specific depth in cases the admixture of fuel oil in the soil has already been solidified (with remaining minimal content of light volatile hydrocarbon factions). Then, the plant rhizosphere creates favourable conditions for the development of heterotrophic and oiloxidizing microorganisms to initiate the process of further destruction of the pollutant, $i$. e. its biodegradation. 


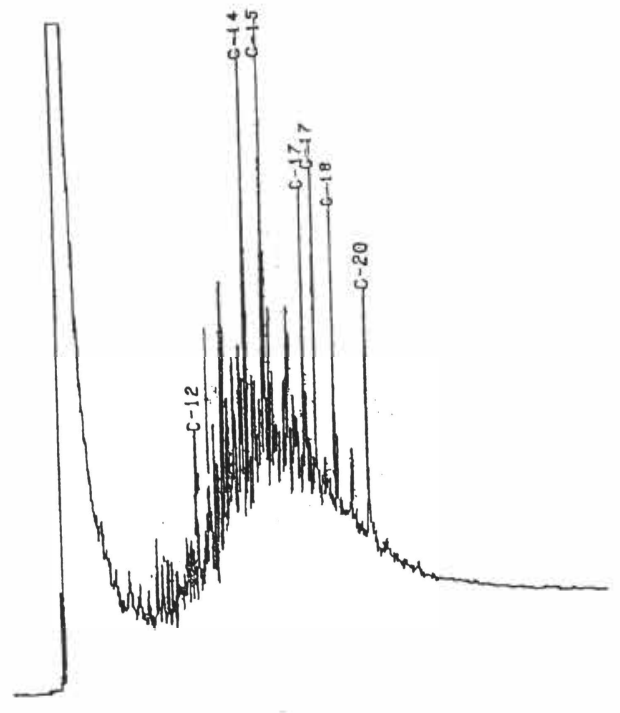

Figure 2. Heavy oil hydrocarbons $\left(C_{10}-C_{20}\right)$ composition in ground

\section{CONCLUSIONS}

To define limitary concentrations of the fuel oil in the soil, or its interventional value (referred to a fuel oil concentration immediately preceding a dangerous for functional properties of the ecosystem), some biological indicators in the forms of plant species and their communities have been used.

It has been established that a limitary concentration of the fuel oil in soils of industrial sites, represented by both KSOT and PRS, is $1 \mathrm{~kg} / \mathrm{m}^{2}$, or approximately $5000 \mathrm{mg}$ per $1 \mathrm{~kg}$ of dry soil, with fuel oil composition being the following (in percentage): paraffin naphtens -15 , olefins and cyclodiolefins -5 , aromatic hydrocarbons -25 , resins -55 .

Totally 271 higher plant species have been recorder at KSOT site. Their floral composition has been typical for technogenic ecotops. Their most part $(71 \%)$ has been composed of plants specific for littoral sand and referral habitats resistant to the anthropogenic influence.

Only 38 plant species have been recorded at PRS site constantly contaminated over its whole area. 
KALMAR ECO-TECH'03

Bioremediation and Leachate Treatment

KALMAR, SWEDEN, November 25-27, 2003

It has been determined that the most resistant to the oil pollution are plants that have long rootstocks and taproots. Those include Calamagrostis epigejos, Carex arenaria, Carex hirta, Elytrigia repens, Leymus arenarius, Poa compressa, Artemisia campestris, Cirsium arvense, Convolvulus arvensis, Equisetum arvense, Tanacetum vulgare, Tussilago farfara. Some of them can be used for introduction to the fuel-oil polluted soil at special biodestruction ranges when the remaining fuel oil concentration is not exceeding 5000 $6000 \mathrm{mg}$ per $1 \mathrm{~kg}$ of the soil.

\section{REFERENCES}

[1] Balevičienè J., 1991: Syntaxonomical - phytogeographical structure of vegetation in Lithuania. - Vilnius (in Russian)

[2] Braun-Blanguet J., 1964: Pflanzensozologie. Grundzüge der Vegetationskunde. Wien, New York, 1964, 86 p.

[3] Charchota A. I., 1989: Flora of technogenic ecotops. In: Problems of investigation of sinantropic flora in USSR. - Moscow, 19-21 p. (in Russian)

[4] Chyžniak N. A., Dacun E. I., 1989: Formation of anthropogenic flora at chemical enterprise. In: Problems of investigation of sinantropic flora in USSR. - Moscow, 25-26 p. (in Russian)

[5] Flora Europaea. 1964-1980: Flora Europaea. 1-5. - Cambridge

[6] Frank D., Klotz S., 1990: Biologisch-ökologische Daten zur Flora der DDR. Halle

[7] Jankevičienè R., 1998, Glossary of botanical names, 523 p. (in Lithuanian)

[8] Klotz S., 1984: Phytoökologische Beitrage zur charakterisierung und Gliederung urbanen ökosysteme, dargestellt am Beispiel der Stadte Halle und Halle-Neustadt. - Halle.

[9] Kunick W., 1974: Veranderung von Flora und Vegetation einer Grossstadt, dargestellt am Beispiel von Berlin (West). - Berlin.

[10] Lapinskienė N., Subterranean part of herbaceous plants and phytocenoses in Lithuanian SSR. 1986 - Vilnius (in Russian)

[11] Matuszkiewicz W., Guide to identification of communities of Poland's vegetation, 1984 - Warsaw (in Polish)

[12] Minibajev R. G., Analysis of oil effect on phytotocomponents of agroecosystems and problems of remediation of oil-contaminated land. In: Issues of dynamics and syntaxonomy of anthropogenic vegetation, 1986, 144-158 p. - Ufa (in Russian) 
[13] Natkevičaitè-Ivanauskienè M. et al., 1963: Lithuanian flora, 2. - Vilnius (in Lithuanian)

[14] Oberdorfer E., 1978: Süddeutshe Pflanzengesellschaften. Teil II. - Stuttgart - New York. Oberdorfer E., 1983: Süddeutshe Pflanzengesellschaften. Teil III. Stuttgart - New York

[15] Pasynkova M. V., Formation of sinantropic communities on wastelands of processing industry. In: Problems of investigation of sinantropic flora in USSR, 1989, 21-23 p. - Moscow (in Russian)

[16] Pustelnikovas O. (Ed.-in-Chief), R eport on contamination with oil products of KSOE and PRS sites, 1994 (in Lithuanian)

[17] Rothmaler W., 1986: Excursionsflora für die Gebiete der DDR und der BRD. 4 Berlin

[18] Snarskis P., 1954: Plant guide of LSSR. - Vilnius (in Lithuanian)

[19] Snarskis P., 1968: Guide to Lithuanian plants. - Vilnius (in Lithuanian)

[20] Terechova E. B., Formation of cenoses on anthropogenic areas in bauxite mining. In: Problems of investigation of sinantropic flora in USSR, 1989, 23-25 p. Moscow (in Russian) 